\title{
Knockout of Angiotensin 1-7 Receptor Mas Worsens the Course of Two-Kidney, One-Clip Goldblatt Hypertension: Roles of Nitric Oxide Deficiency and Enhanced Vascular Responsiveness to Angiotensin II
}

\author{
Dan Rakušan ${ }^{a, b}$ Marcela Bürgelovác Ivana Vaněčkováb, d \\ Zdeňka Vaňourkováb, d Zuzana Huskováb,d Petra Škaroupkováb Iveta Mrázováb \\ Martin Opočenskýb Herbert J. Kramer ${ }^{f}$ Ivan Netukad Jan Malýb \\ Natalia Aleninag ${ }^{9}$ Michael Bader ${ }^{g}$ Robson A.S. Santos ${ }^{\text {h }}$ Luděk Červenka $^{\text {b, }}$ d, e \\ ${ }^{a}$ 1st Department of Medicine, Thomayer Teaching Hospital, ${ }^{b}$ Department for Experimental Medicine, Institute \\ for Clinical and Experimental Medicine, 'Department of Nephrology, Transplant Center, Institute for Clinical and \\ Experimental Medicine, ${ }^{\mathrm{d} C e n t e r}$ for Cardiovascular Research, and ${ }^{\mathrm{e}}$ Department of Physiology, 2nd Faculty of

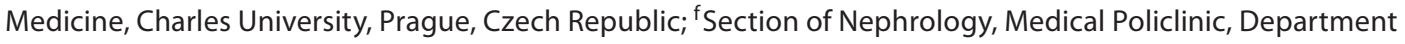 \\ of Medicine, University of Bonn, Bonn, and ${ }^{9}$ Max Delbrück Center for Molecular Medicine, Berlin, Germany; \\ ${ }^{h}$ Department of Physiology and Biophysics, Federal University of Minas Gerais, Belo Horizonte, Brazil
}

\section{Key Words}

Two-kidney, one-clip Goldblatt hypertension .

Mas receptor knockout mice $\cdot$ Nitric oxide deficiency

\begin{abstract}
Aims: The present study was performed to evaluate the effects of target disruption of the G-protein-coupled receptor Mas for angiotensin 1-7 [Ang(1-7)] in knockout mice on the course of two-kidney, one-clip (2K1C) Goldblatt hypertension. Methods: Knockout and wild-type mice underwent clipping of one renal artery. Blood pressure (BP) was monitored by radiotelemetry. The mice were either untreated or chronically treated with the superoxide $\left(\mathrm{O}_{2}^{-}\right)$scavenger tempol $(400 \mathrm{mg} / \mathrm{l})$ or the inhibitor of NADPH oxidase apocynin (1 $\mathrm{g} / \mathrm{l}$ ) administered in drinking water. Results: Knockout mice responded to clipping by accelerated increases in BP and the final BP was significantly higher than that in wildtype mice. Chronic treatment with tempol or apocynin elic-
\end{abstract}

ited similar antihypertensive effects in $2 \mathrm{~K} 1 \mathrm{C} / \mathrm{knockout}$ as in $2 \mathrm{~K} 1 \mathrm{C} /$ wild-type mice. Acute nitric oxide synthase inhibition caused greater BP increases in $2 \mathrm{~K} 1 \mathrm{C}$ /wild-type than in $2 \mathrm{~K} 1 \mathrm{C}$ / knockout mice. Conclusion: Our present findings support the notion that the angiotensin-converting enzyme 2-Ang(17)-Mas axis serves as an important endogenous physiological counterbalancing mechanism that partially attenuates the hypertensinogenic actions of the activated renin-angiotensin system. The impairment in this axis may contribute to the deterioration of the course of $2 \mathrm{~K} 1 \mathrm{C}$ Goldblatt hypertension.

Copyright $\odot 2010$ S. Karger AG, Basel

\section{Introduction}

The two-kidney, one-clip (2K1C) Goldblatt model of hypertension strongly resembles human renovascular hypertension. It is well established that in this model the renin-angiotensin system (RAS) plays an important role

\section{KARGER}

Fax +41613061234 E-Mail karger@karger.ch www.karger.com

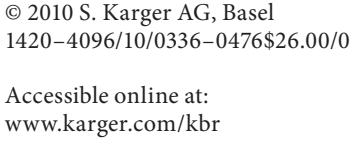

Luděk Červenka, $\mathrm{MD}, \mathrm{PhD}$

Department for Experimental Medicine

Institute for Clinical and Experimental Medicine, 1958/9 Vídeňská

CZ-140 00 Prague 4 (Czech Republic)

Tel. +420 26136 2126, Fax +42024172 1666, E-Mail luce@ medicon.cz 
in the development and maintenance of hypertension. Previous studies have also clearly shown that angiotensin II (Ang II) is the biologically most important peptide of the RAS and that Ang II-mediated activation of Ang II type 1 receptors is the critical mechanism in the pathophysiology of 2K1C Goldblatt hypertension $[1,2]$. Nevertheless, recent studies have demonstrated that in the phase of sustained hypertension the enhanced plasma Ang II level is not the exclusive causative factor responsible for the maintenance of hypertension in this model and therefore the role of other components of the RAS and/or their interaction with other vasoactive system(s) must be evoked $[3,5]$.

Emerging evidence indicates that angiotensin 1-7 [Ang(1-7)], a biologically active heptapeptide which is mainly formed by angiotensin-converting enzyme 2 (ACE2), acts as a vasodilator and natriuretic peptide which can be considered as an endogenous physiological Ang II counterbalancing peptide within the RAS [6-8]. The importance of Ang(1-7) has been underlined by the findings that the G-protein-coupled Mas receptor is the endogenous binding site for Ang(1-7) and through its activation the majority of actions of Ang(1-7) are mediated [9-12]. In our recent study, we have shown that either chronic pharmacological blockade of Ang(1-7) receptors by infusion of 7-D-Ala-Ang(1-7) or chronic treatment with an ACE2 inhibitor worsened the course of hypertension and elicited a significant reduction of renal hemodynamics in the nonclipped kidney of 2K1C Goldblatt hypertensive rats without altering circulating and intrarenal Ang II levels as compared with saline vehicle-infused $2 \mathrm{~K} 1 \mathrm{C}$ hypertensive rats. These data suggest that Ang(1-7) serves as an important endogenous vasodilatory and renoprotective agent that, at least partially, attenuates the vasoconstrictor actions of elevated intrarenal Ang II levels in the nonclipped kidney of $2 \mathrm{~K} 1 \mathrm{C}$ hypertensive rats $[13,14]$. On the basis of these results, it has been postulated that either a deficiency in intrarenal Ang(1-7) formation or an interrupted signaling within the endogenous ACE2-Ang(1-7) axis might contribute to the deterioration of the course of hypertension in the $2 \mathrm{~K} 1 \mathrm{C}$ Goldblatt hypertensive model.

Some conflicting data from previous studies evaluating the physiological and pathophysiological role of Ang(1-7) have been ascribed to nonspecific and/or related actions of $\operatorname{Ang}(1-7)$ receptor antagonists and agonists $[6,7,15]$. In order to overcome some of these limitations and to address some criticism regarding the conclusions drawn from our previous studies which predominantly used a pharmacological approach to study the role of the ACE2-Ang(1-7) axis in the regulation of blood pressure (BP) and renal function $[13,14,16,17]$, we have decided to employ in the present study genetically engineered mice with target disruption of the Mas receptor (knockout mice). In a first series of experiments, the effects of a chronic functional lack of actions of endogenous Ang(1-7) on the development of 2K1C Goldblatt hypertension were evaluated.

Emerging evidence indicates that enhanced nitric oxide (NO) formation counteracts the hypertensinogenic actions of elevated Ang II levels in Ang II-dependent forms of hypertension $[4,18,19]$, since it has been shown that Ang(1-7)-induced vasodilatation is predominantly NO dependent and that NO release occurs through Mas receptor-mediated actions of Ang(1-7) that elicits sitespecific phosphorylation/dephospohrylation of endothelial NO synthase (NOS) $[6,11,20,21]$. Accordingly, the second aim of the present study was to assess the effects of acute NOS inhibition with nitro-L-arginine methyl ester (L-NAME) on BP in sham-operated and 2K1C knockout and wild-type mice.

Recently, we have demonstrated that during the maintenance phase of hypertension 2K1C mice exhibit enhanced oxidative stress which decreased NOS-dependent vasodilatation when compared with the initial hypertensive phase. Moreover, it has been suggested that increased production of superoxide anion $\left(\mathrm{O}_{2}^{-}\right)$might be an important factor contributing to the maintenance of hypertension in 2K1C mice [4, 22], and Ang (1-7) has been demonstrated to attenuate Ang II-induced $\mathrm{O}_{2}^{-}$in endothelial cells [23]. In view of the above-mentioned information, we hypothesized that interruption of the ACE2-Ang(17)-Mas axis might further increase the $\mathrm{O}_{2}^{-}$formation and contribute to the worsening of the course of $2 \mathrm{~K} 1 \mathrm{C}$ Goldblatt hypertension. Accordingly, the third aim of the present study was to evaluate whether chronic treatment with either the membrane-permeable, metal-independent superoxide dismutase mimetic 4-hydroxyl-2,2,6,6tetramethyl piperidinoxyl (tempol), which has been shown to be a stable spin trap and to scavenge $\mathrm{O}_{2}^{-}$in many in vitro as well as in vivo studies [24-27], or whether chronic administration of apocynin, which has been shown to act as an antioxidant in vascular tissue [27, 28], will attenuate the course of hypertension after unilateral renal artery clipping and the $\mathrm{BP}$ responses to acute NOS inhibition with L-NAME in knockout and wild-type mice.

Furthermore, to gain a more detailed insight into the role of both axes of the RAS in the pathophysiology of $2 \mathrm{~K} 1 \mathrm{C}$ hypertension in mice, Ang II and Ang(1-7) concen- 
trations in plasma and in the nonclipped kidney were assessed.

Finally, to elucidate whether the genetically engineered interruption of the ACE2-Ang(1-7)-Mas axis selectively alters vasomotor responses to Ang II, additional experiments were performed to assess $\mathrm{BP}$ responses to Ang II and norepinephrine in untreated and tempol- and apocynin-treated sham-operated and $2 \mathrm{~K} 1 \mathrm{C}$ hypertensive knockout and wild-type mice.

\section{Methods}

The studies were performed in accordance with guidelines and practices established by the Animal Care and Use Committee of the Institute for Clinical and Experimental Medicine (protocol No. 2006). All animals used in the present study were bred at the Department for Experimental Medicine from stock animals supplied by the Max Delbrück Center for Molecular Medicine, Berlin, Germany (we acknowledge the generous gift of Michael Bader). In order to obtain knockout mice on pure genetic background the originally heterozygous mice on mixed genetic background were backcrossed to the inbred FVB/N mouse line.

\section{Series 1: Evaluation of the Development of 2K1C Goldblatt}

Hypertension in Knockout and Wild-Type Mice - Effects of

Tempol and Apocynin Treatment

Male wild-type and knockout mice weighing 28-32 g were anesthetized with a combination of ketamine $(90 \mathrm{mg} / \mathrm{kg}$ i.p.) and xylazine $(10 \mathrm{mg} / \mathrm{kg}$ i.p.) and TA11PA-C10 radiotelemetric probes (Data Sciences International, St. Paul, Minn., USA) were implanted in the left carotid artery, as described previously in detail and as used in our recent study [4]. Mice were allowed 5 days to recover, after which time basal BP was recorded for 7 days and subsequently 2K1C Goldblatt hypertensive and sham-operated mice were prepared. $2 \mathrm{~K} 1 \mathrm{C}$ mice were prepared in a similar way as described previously $[4,22]$. Antioxidant treatment with the $\mathrm{O}_{2}^{-}$ scavenger tempol (Sigma, Prague, Czech Republic) at a dose of 400 $\mathrm{mg} / \mathrm{l}$ or the NADPH oxidase inhibitor apocynin at a dose of $1 \mathrm{~g} / \mathrm{l}$ were given in drinking water starting after clip placement and administered until the end of the experiment (day 25 after clip placement). Previous studies have shown that these doses of tempol and apocynin can effectively reduce oxidative stress [26-28]. Apocynin was sonicated with cyclodextrin $(1 \mathrm{~g} / \mathrm{l})$ in $2 \mathrm{ml}$ of ethanol and dissolved in 1 liter of water. Our preliminary study has shown that this solution of cyclodextrin itself did not affect BP or renal excretory parameters in mice. The drinking water solutions were filled into covered bottles to minimize degradation by light and were changed every second day.

Direct BP measurement by radiotelemetry was conducted in the following experimental groups of G-protein-coupled receptor Mas wild-type and knockout mice:

(1) sham-operated wild-type mice (wild-type mice, $\mathrm{n}=5$ );

(2) sham-operated wild-type mice treated with tempol (wildtype mice + tempol, $\mathrm{n}=5$ );

(3) sham-operated wild-type mice treated with apocynin (wild-type mice + apocynin, $\mathrm{n}=5$ );
(4) sham-operated knockout mice (knockout mice, $\mathrm{n}=5$ );

(5) sham-operated knockout mice treated with tempol (knockout mice + tempol, $\mathrm{n}=5$ );

(6) sham-operated knockout mice treated with apocynin (knockout mice + apocynin, $\mathrm{n}=5$ );

(7) $2 \mathrm{~K} 1 \mathrm{C}$ wild-type mice (2K1C/wild-type mice, $\mathrm{n}=7$ );

(8) $2 \mathrm{~K} 1 \mathrm{C}$ wild-type mice treated with tempol (2K1C/wild-type mice + tempol, $\mathrm{n}=7$ );

(9) $2 \mathrm{~K} 1 \mathrm{C}$ wild-type mice treated with apocynin $(2 \mathrm{~K} 1 \mathrm{C} /$ wildtype mice + apocynin, $\mathrm{n}=7$ );

(10) $2 \mathrm{~K} 1 \mathrm{C}$ knockout mice $(2 \mathrm{~K} 1 \mathrm{C} /$ knockout mice, $\mathrm{n}=8)$;

(11) $2 \mathrm{~K} 1 \mathrm{C}$ knockout mice treated with tempol $(2 \mathrm{~K} 1 \mathrm{C} /$ knockout mice + tempol, $\mathrm{n}=8$ );

(12) $2 \mathrm{~K} 1 \mathrm{C}$ knockout mice treated with apocynin $(2 \mathrm{~K} 1 \mathrm{C} /$ knockout mice + apocynin, $\mathrm{n}=7$ ).

Twenty-four-hour urine samples were collected in conscious mice using metabolic cages 2 days before the clip placement and the start of the treatment protocol to establish basal renal excretory parameters and subsequently on days 7, 14, 21 and 25 of the experiment. Urinary concentrations of sodium and potassium were assessed by flame photometry. Concentration of 8 -isoprostane was determined by enzyme immunoassay (Cayman Chemical, Prague) and nitrate/nitrite concentration was measured using a colorimetric assay (Cayman Chemical, Prague). At the end of the experiment, mice were sacrificed with excess intraperitoneal thiopental. The kidneys and hearts were excised, drained and weighed.

Series 2: Assessment of the Effects of Acute NOS Inhibition on Mean Arterial Pressure in Knockout and Wild-Type Mice

Separate groups of mice were anesthetized with thiopental sodium $(60 \mathrm{mg} / \mathrm{kg}$, i.p.) and placed on a servo-controlled surgical table that maintained body temperature at $37^{\circ} \mathrm{C}$. A tracheostomy was performed using PE-90 tubing. The mice were allowed to breathe air enriched with $\mathrm{O}_{2}$. The right carotid artery was cannulated with a PE-10 catheter connected to a PE-50 catheter for continuous measurement of mean arterial pressure (MAP) with a pressure transducer (model MLT 1050). For recording a computerized data acquisition system (PowerLab/4SP, ADInstruments, UK) was used. In addition, the right jugular vein was catheterized with PE-10 tubing for infusion of saline containing $1 \%$ bovine serum albumin (Sigma Chemical Co.) at a rate of $5 \mu \mathrm{l} / \mathrm{min}$ throughout the experiment. After surgery mice were allowed a 10 -min recovery period which was followed by a 25 -min control period for measurements of basal MAP. Acute NOS inhibition was achieved by intravenous bolus administration of L-NAME (Sigma Chemical Co.; $1 \mathrm{mg} / \mathrm{kg}$ ) which was dissolved in $50 \mu \mathrm{l}$, and then a continuous infusion of L-NAME $\left(0.25 \mu \mathrm{g} \cdot \mathrm{g}\right.$ body weight $\left.{ }^{-1} \cdot \mathrm{min}^{-1}\right)$ was employed throughout the experiment. The dose of L-NAME used in the present study was validated in our previous study [4]. Time control mice received a constant saline vehicle infusion throughout the experiment. At the end of the experiment, mice were sacrificed with an excess dose of intravenous thiopental sodium. The following experimental groups of G-protein-coupled receptor Mas wild-type and knockout mice ( $\mathrm{n}=7$ in each group) were examined on day 26 after clip placement or sham operation:

(1) sham-operated wild-type mice;

(2) sham-operated wild-type mice + tempol;

(3) sham-operated wild-type mice + apocynin;

(4) sham-operated knockout mice; 
(5) sham-operated knockout mice + tempol;

(6) sham-operated knockout mice + apocynin;

(7) $2 \mathrm{~K} 1 \mathrm{C} /$ wild-type mice;

(8) $2 \mathrm{~K} 1 \mathrm{C} /$ wild-type mice + tempol;

(9) $2 \mathrm{~K} 1 \mathrm{C} /$ wild-type mice + apocynin;

(10) $2 \mathrm{~K} 1 \mathrm{C} /$ knockout mice;

(11) $2 \mathrm{~K} 1 \mathrm{C} / \mathrm{knockout} \mathrm{mice} \mathrm{+} \mathrm{tempol;}$

(12) $2 \mathrm{~K} 1 \mathrm{C} /$ knockout mice + apocynin.

Series 3: Determinations of Plasma and Kidney Tissue Ang II and Ang(1-7) Concentrations

It is now recognized that plasma and tissue Ang II concentrations in anesthetized animals are higher than those obtained from decapitated conscious rats and that normotensive animals exhibit greater increases in renin secretion in response to anesthesia and surgery than Ang II-dependent hypertensive intrarenal renin-depleted animals [29]. Therefore, in the present study, Ang II and Ang(1-7) levels were determined in plasma and in nonclipped kidneys and hearts in separate experimental groups of the above-described mice ( $n=8$ in each group). At the end of the experiments (on day 26 after clip placement or sham operation), mice were sacrificed by decapitation, and plasma and tissue Ang II levels were assessed by radioimmunoassay (RIA) based on the procedure developed by Fox et al. [30] and further modified and validated in our laboratory $[4,5,14,27,31-33]$. This approach for blood and tissue sampling and Ang II assay, which is routinely used in our laboratory, allows us to compare the present results with those of our previous studies evaluating the role of RAS in the pathophysiology of hypertension [4, 5, 14, 27, 31-33]. Ang(1-7) was measured by RIA similar to methods employed in previous studies by other laboratories using the antibody produced by our laboratory. This RIA method for Ang(1-7) determination was recently introduced and validated in our laboratory in $2 \mathrm{~K} 1 \mathrm{C}$ Goldblatt hypertensive rat [14].

Series 4: Assessment of MAP Responses to Bolus Doses of Ang II and Norepinephrine

In this series, wild-type and knockout mice were subjected to the same experimental design as described in series 1 . On day 26 of the experiment, mice were anesthetized (thiopental sodium, 60 $\mathrm{mg} / \mathrm{kg}$, i.p.) and prepared as described in series 2 . After a 20 -min equilibration period, the experimental protocol was started to assess the responses of MAP to increasing systemic (intravenous) bolus doses of vasoactive hormones. The vasoactive agents were dissolved in $50 \mu \mathrm{l}$ of isotonic saline and after intravenous administration a bolus of $50 \mu \mathrm{l}$ of isotonic saline was administrated to ensure a rapid and complete delivery of the vasoactive agent into the systemic circulation. We and others have demonstrated in previous studies that a 5 -min period between injections is sufficient to permit the return of MAP to basal values [31, 34, 35]. MAP responses to intravenous bolus doses of Ang II (10 and $25 \mathrm{ng}$ ) and thereafter of norepinephrine (50 and $150 \mathrm{ng}$ ) were studied in the following experimental groups of G-protein-coupled receptor Mas wild-type and knockout mice ( $\mathrm{n}=8$ in each group):

(1) sham-operated wild-type mice;

(2) sham-operated wild-type mice + tempol;

(3) sham-operated wild-type mice + apocynin;

(4) sham-operated knockout mice;

(5) sham-operated knockout mice + tempol;

(6) sham-operated + apocynin;

2K1C Hypertension in Mas Receptor Knockout Mice
(7) $2 \mathrm{~K} 1 \mathrm{C} /$ wild-type mice;

(8) $2 \mathrm{~K} 1 \mathrm{C} /$ wild-type mice + tempol;

(9) $2 \mathrm{~K} 1 \mathrm{C} /$ wild-type mice + apocynin;

(10) $2 \mathrm{~K} 1 \mathrm{C} /$ knockout mice;

(11) $2 \mathrm{~K} 1 \mathrm{C} / \mathrm{knockout}$ mice + tempol;

(12) $2 \mathrm{~K} 1 \mathrm{C} /$ knockout mice + apocynin.

Statistical Analyses

All values are expressed as means \pm SEM. With GraphPad Prism software (GraphPad Software, San Diego, Calif., USA), statistical analysis was performed using Student's t test, Wilcoxon's signed-rank test for unpaired data, or one-way ANOVA when appropriate. ANOVA for repeated measurements, followed by Student-Newman-Keuls test was performed for the analysis within groups (e.g. for the analysis of BP changes after clip placement). Values exceeding the $95 \%$ probability limits $(p<0.05)$ were considered statistically significant.

\section{Results}

Series 1: Development of 2K1C Goldblatt

Hypertension in Knockout and Wild-Type Mice Effects of Tempol and Apocynin Treatment

As shown in figure 1a, basal values of MAP did not differ between wild-type and knockout mice (100 \pm 2 vs. $102 \pm 2 \mathrm{~mm} \mathrm{Hg}$ ). MAP remained unchanged in shamoperated mice throughout the duration of the study. MAP in $2 \mathrm{~K} 1 \mathrm{C} /$ wild-type mice exhibited progressive increases during the duration of the study reaching a value of $142 \pm 2 \mathrm{~mm} \mathrm{Hg}$ on day 25 . In comparison, $2 \mathrm{~K} 1 \mathrm{C} /$ knockout mice exhibited earlier onset of hypertension and MAP reached significantly higher levels compared to $2 \mathrm{~K} 1 \mathrm{C} /$ wild-type mice on day $25(152 \pm 2$ vs. $142 \pm$ $2 \mathrm{~mm} \mathrm{Hg}$ ). As shown in figure $1 \mathrm{~b}$, tempol or apocynin did not modify the development of hypertension in $2 \mathrm{~K} 1 \mathrm{C} /$ wild-type mice but treatment with tempol and apocynin starting from day 15 attenuated the level of MAP on day 25 after clipping being significantly lower than in untreated $2 \mathrm{~K} 1 \mathrm{C} /$ wild-type mice $(125 \pm 2$ and $124 \pm 2$ vs. $142 \pm 2 \mathrm{~mm} \mathrm{Hg}, \mathrm{p}<0.05$ in both cases). Likewise, treatment with tempol and apocynin did not alter the course of hypertension in $2 \mathrm{~K} 1 \mathrm{C} / \mathrm{knockout}$ mice and ameliorated the degree of hypertension from day 16 on after clip placement resulting in a significantly lower MAP on day 25 after clipping than in untreated $2 \mathrm{~K} 1 \mathrm{C} /$ knockout mice $(134 \pm 2$ and $136 \pm 2$ vs. $152 \pm 2 \mathrm{~mm} \mathrm{Hg}, \mathrm{p}<0.05$ in both cases) (fig. 1c). Neither tempol nor apocynin altered MAP in sham-operated wild-type and knockout mice.

As shown in figure 1d, cardiac hypertrophy (expressed as a ratio of heart weight to body weight) closely correlated with the changes in MAP after clipping and with the 

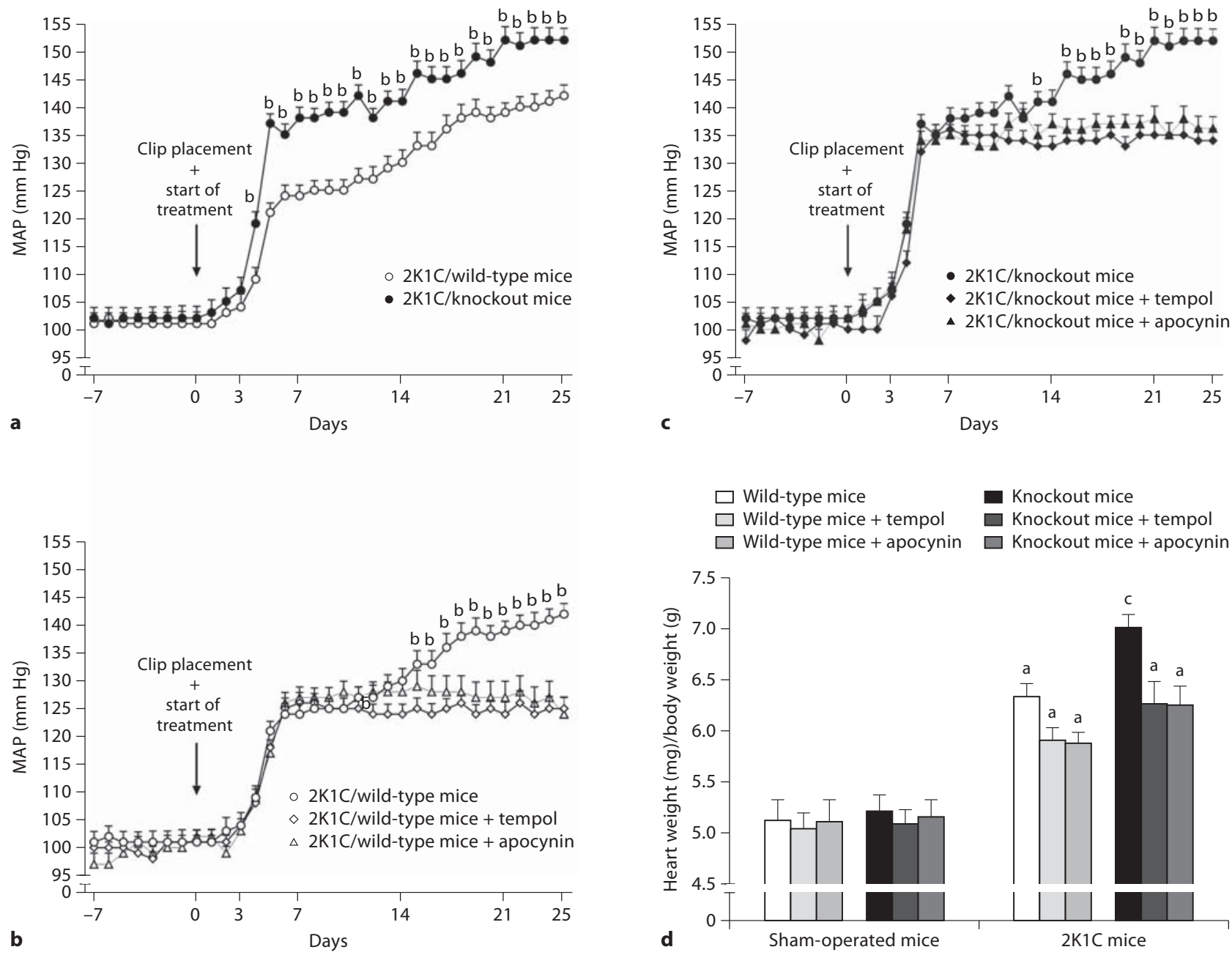

Knockout mice

Knockout mice + tempol

$\square$ Wild-type mice + apocynin $\square$ Knockout mice + apocynin

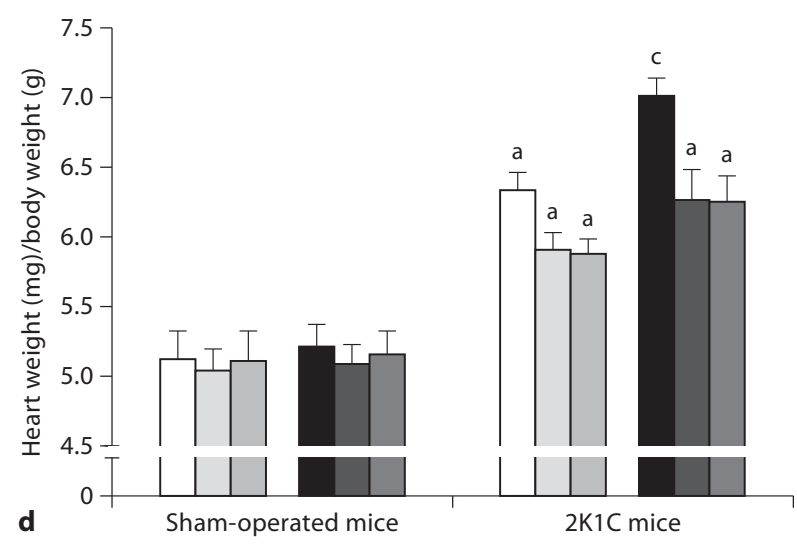

Fig. 1. a-c MAP (measured by radiotelemetry) after clip placement in conscious mice. $\mathbf{d}$ Ratio of heart weight and body weight at the end of experiment. Tempol and apocynin = Chronic administration of these drugs in drinking water. ${ }^{a} \mathrm{p}<0.05$ compared with sham-operated mice; ${ }^{\mathrm{b}} \mathrm{p}<0.05$ compared with unmarked values at the same time point; ${ }^{c} \mathrm{p}<0.05$ compared with all other values.

effects of tempol and apocynin on the course of hypertension in $2 \mathrm{~K} 1 \mathrm{C}$ mice.

As shown in figure 2a, basal urinary 8-isoprostane excretion (before clipping) was not significantly different between wild-type and knockout mice $(1.76 \pm 0.19$ and $1.84 \pm 0.22 \mathrm{ng} / 24 \mathrm{~h}$ ) and remained unaltered until day 14 after clip placement. On days 21 and 25 after clipping, urinary excretion of 8 -isoprostane in $2 \mathrm{~K} 1 \mathrm{C} /$ wild-type and $2 \mathrm{~K} 1 \mathrm{C} / \mathrm{knockout}$ mice was significantly higher than baseline values $(2.76 \pm 0.26$ and $3.06 \pm 0.21$ and $2.65 \pm$ 0.14 and $3.12 \pm 0.14$ vs. $1.76 \pm 0.19$ and $1.84 \pm 0.22$ $\mathrm{ng} / 24 \mathrm{~h}$, respectively, $\mathrm{p}<0.05$ in all cases). Chronic tempol and apocynin treatment prevented the increase in urinary 8 -isoprostane excretion in $2 \mathrm{~K} 1 \mathrm{C} /$ wild-type and $2 \mathrm{~K} 1 \mathrm{C} / \mathrm{knockout}$ mice, i.e. the levels were not significantly different from basal values.

As shown in figure $2 \mathrm{~b}$, the basal daily urinary excretion of NO metabolites, determined as nitrate/nitrite, was not significantly different between wild-type and knockout mice $(0.31 \pm 0.08$ and $0.33 \pm 0.09 \mu \mathrm{mol} /$ day $)$. Clip placement resulted in significant increases in nitrate/nitrite excretion in wild-type as well as in knockout mice. 
Fig. 2. Urinary 8-isoprostane (a) and nitrate/nitrite excretion (b) in $2 \mathrm{~K} 1 \mathrm{C}$ mice. Tempol and apocynin: chronic administration of these drugs in drinking water. ${ }^{a} \mathrm{p}<0.05$ compared with unmarked values at the same time point; ${ }^{\mathrm{b}} \mathrm{p}<0.05$ compared with values marked by superscript a at the same time point; ${ }^{\mathrm{c}} \mathrm{p}<0.05$ compared with all other values at the same time point.
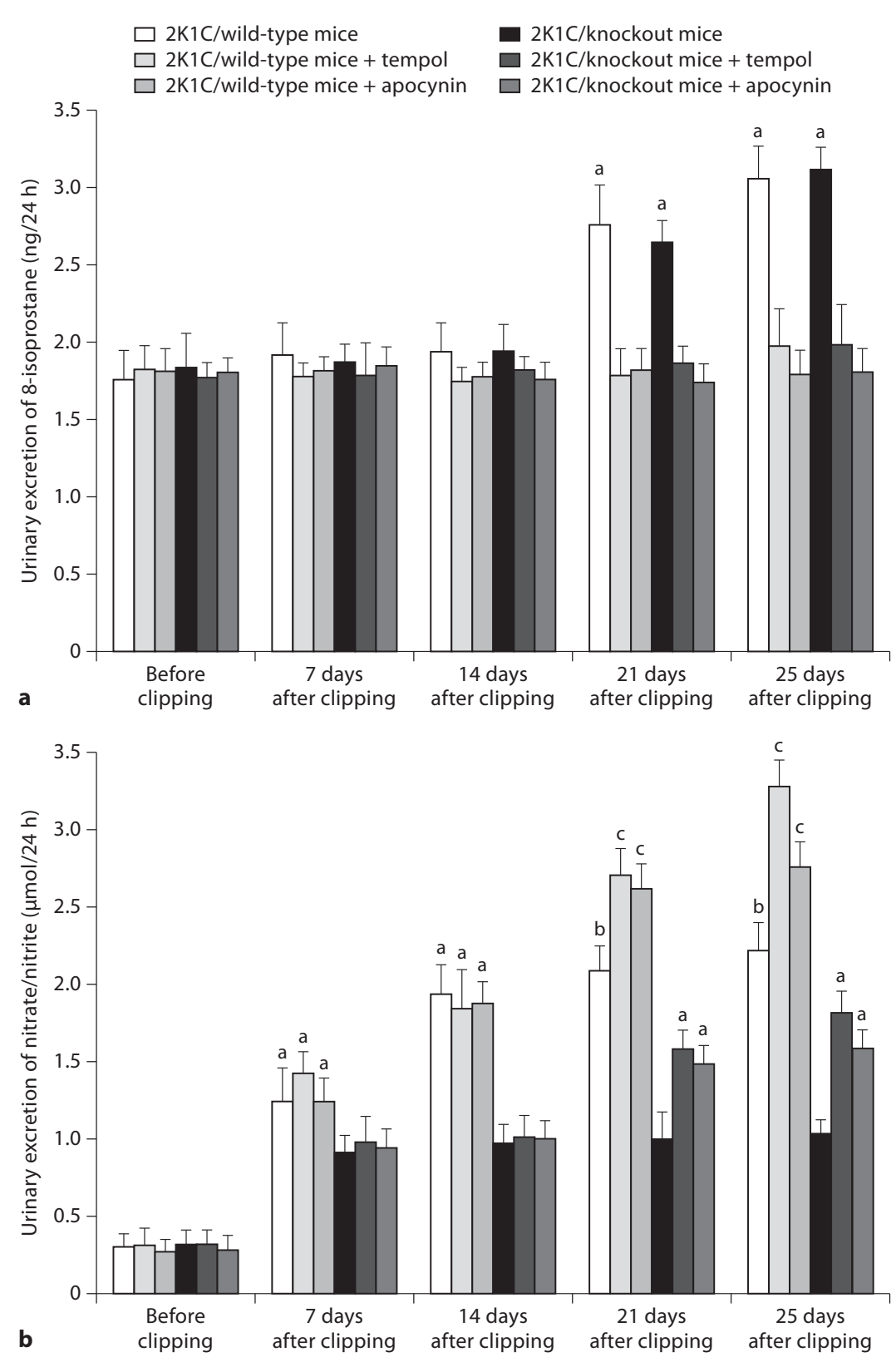

However, increases in nitrate/nitrite excretion in $2 \mathrm{~K} 1 \mathrm{C} /$ wild-type mice were markedly higher than in $2 \mathrm{~K} 1 \mathrm{C} /$ knockout mice reaching a maximum on day 25 after clipping $(2.28 \pm 0.18$ vs. $1.04 \pm 0.09 \mu \mathrm{mol} / \mathrm{day}, \mathrm{p}<0.05)$. Chronic tempol and apocynin treatment increased urinary excretion of nitrate/nitrite on days 21 and 25 after clipping in $2 \mathrm{~K} 1 \mathrm{C} /$ wild-type mice as well as $2 \mathrm{~K} 1 \mathrm{C} / \mathrm{knock}$ - out mice when compared with untreated $2 \mathrm{~K} 1 \mathrm{C} /$ wild-type and $2 \mathrm{~K} 1 \mathrm{C} /$ knockout mice (fig. $2 \mathrm{~b}$ ).

Sham-operated wild-type and knockout mice did not exhibit significant changes in urinary 8-isoprostane and nitrate/nitrite excretion throughout the experiment and neither tempol nor apocynin treatment altered their urinary excretion. 


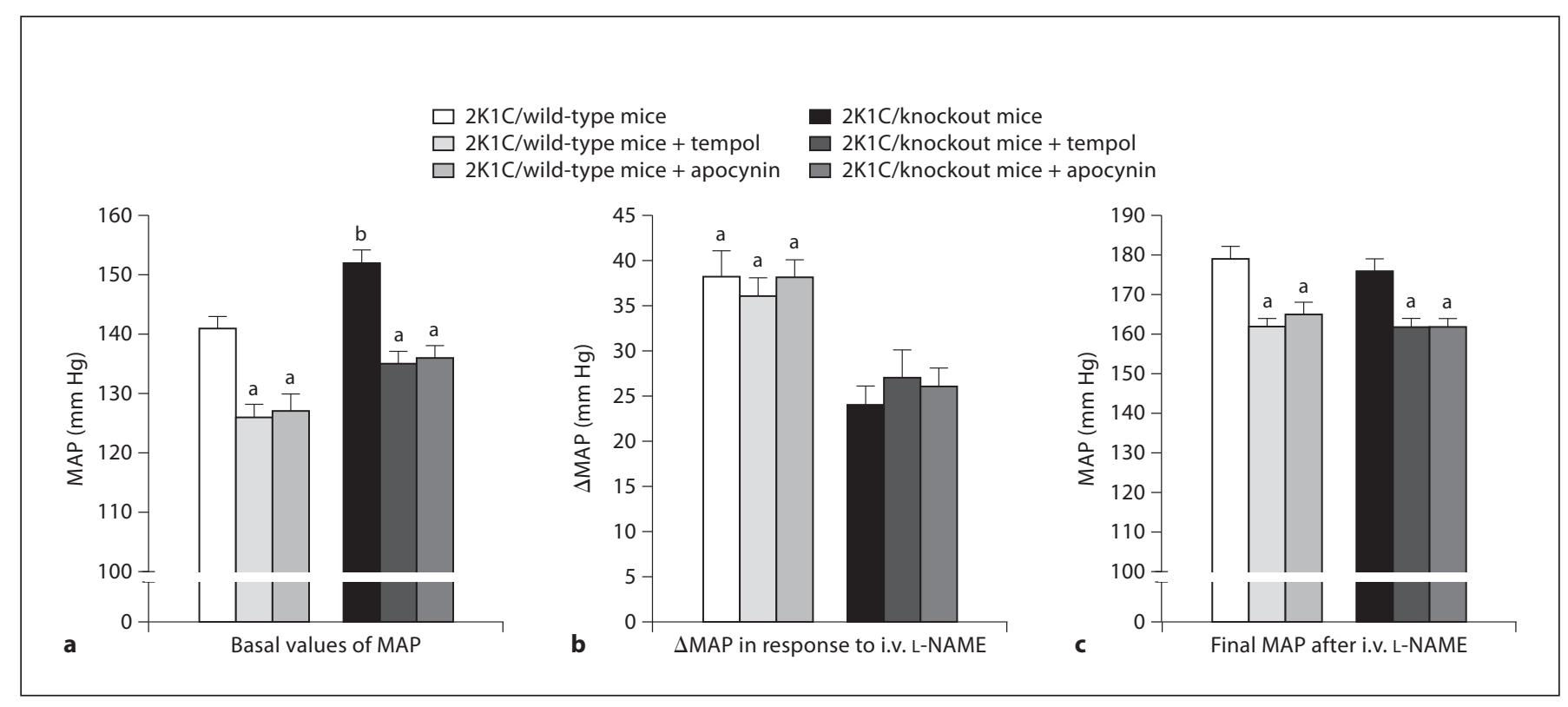

Fig. 3. MAP measured 26 days after clip placement (a), changes in MAP after acute NOS inhibition (b) and final MAP after acute NOS inhibition (c) in wild-type and knockout mice. Tempol and apocynin: chronic administration of these drugs in drinking water. ${ }^{\mathrm{a}} \mathrm{p}<0.05$ compared with unmarked values; ${ }^{\mathrm{b}} \mathrm{p}<0.05$ compared with all other values.

\section{Series 2: Effects of Acute NOS Inhibition with L-NAME on MAP}

Similar to radiotelemetric data in conscious mice, basal values of MAP in anesthetized sham-operated wildtype and knockout mice were not significantly different (102 \pm 2 vs. $103 \pm 2 \mathrm{~mm} \mathrm{Hg})$ and chronic treatment with either tempol or apocynin did not cause significant changes in MAP. In addition, acute NOS inhibition induced similar increases in tempol- and apocynin-treated sham-operated wild-type and knockout mice $(+14 \pm 2$, $+12 \pm 2$ and $+13 \pm 2,+12 \pm 3 \mathrm{~mm} \mathrm{Hg}$ ). The final MAP after NOS inhibition was not significantly different among the experimental groups.

As shown in figure $3 \mathrm{a}$, basal values of MAP were significantly higher in $2 \mathrm{~K} 1 \mathrm{C} /$ knockout mice than in $2 \mathrm{~K} 1 \mathrm{C} /$ wild-type mice $(152 \pm 2$ vs. $141 \pm 2 \mathrm{~mm} \mathrm{Hg}, \mathrm{p}<0.05)$. Chronic treatment with tempol and apocynin significantly lowered MAP in 2K1C/wild-type mice (126 \pm 2 and $127 \pm 3 \mathrm{~mm} \mathrm{Hg}$, respectively) as well as in $2 \mathrm{K1C} /$ knockout mice (135 \pm 2 and $136 \pm 2 \mathrm{~mm} \mathrm{Hg}$, respectively). Figure $3 \mathrm{~b}$ shows that $2 \mathrm{~K} 1 \mathrm{C} /$ wild-type mice responded to acute NOS inhibition with a significantly greater increase in MAP than $2 \mathrm{~K} 1 \mathrm{C} /$ knockout mice $(+38$ \pm 3 vs. $+24 \pm 2 \mathrm{~mm} \mathrm{Hg}, \mathrm{p}<0.05$ ), such that MAP levels in $2 \mathrm{~K} 1 \mathrm{C} /$ wild-type mice after NOS inhibition approached those of 2K1C/knockout mice (fig. 3c). The responses of MAP to L-NAME administration were unaffected by either tempol or apocynin.

\section{Series 3: Plasma and Tissue Ang II and Ang(1-7) \\ Concentrations}

As shown in figure $4 \mathrm{a}$, there were no significant differences in plasma Ang II levels on day 26 after clip placement or sham operation between wild-type and knockout mice.

Figure $4 \mathrm{~b}$ shows that the intrarenal content of Ang II in sham-operated wild-type and knockout mice was not significantly different and was not altered by tempol or apocynin. Whole kidney Ang II levels in the nonclipped kidney of $2 \mathrm{~K} 1 \mathrm{C}$ mice on day 26 were significantly higher than those of sham-operated mice. However, they were not significantly different between wild-type and knockout mice $(248 \pm 36$ and $229 \pm 37$ vs. $137 \pm 14$ and 122 $\pm 15 \mathrm{fmol} / \mathrm{g}$, respectively, $\mathrm{p}<0.05$ in both cases) and were unaffected either by tempol or apocynin.

Figure 4c shows that plasma Ang(1-7) was not significantly different between sham-operated wild-type and knockout mice ( $9 \pm 3$ vs. $14 \pm 2 \mathrm{fmol} / \mathrm{ml})$. Plasma Ang(17) increased significantly after clip placement as compared with sham-operated mice. However, plasma Ang(1- 


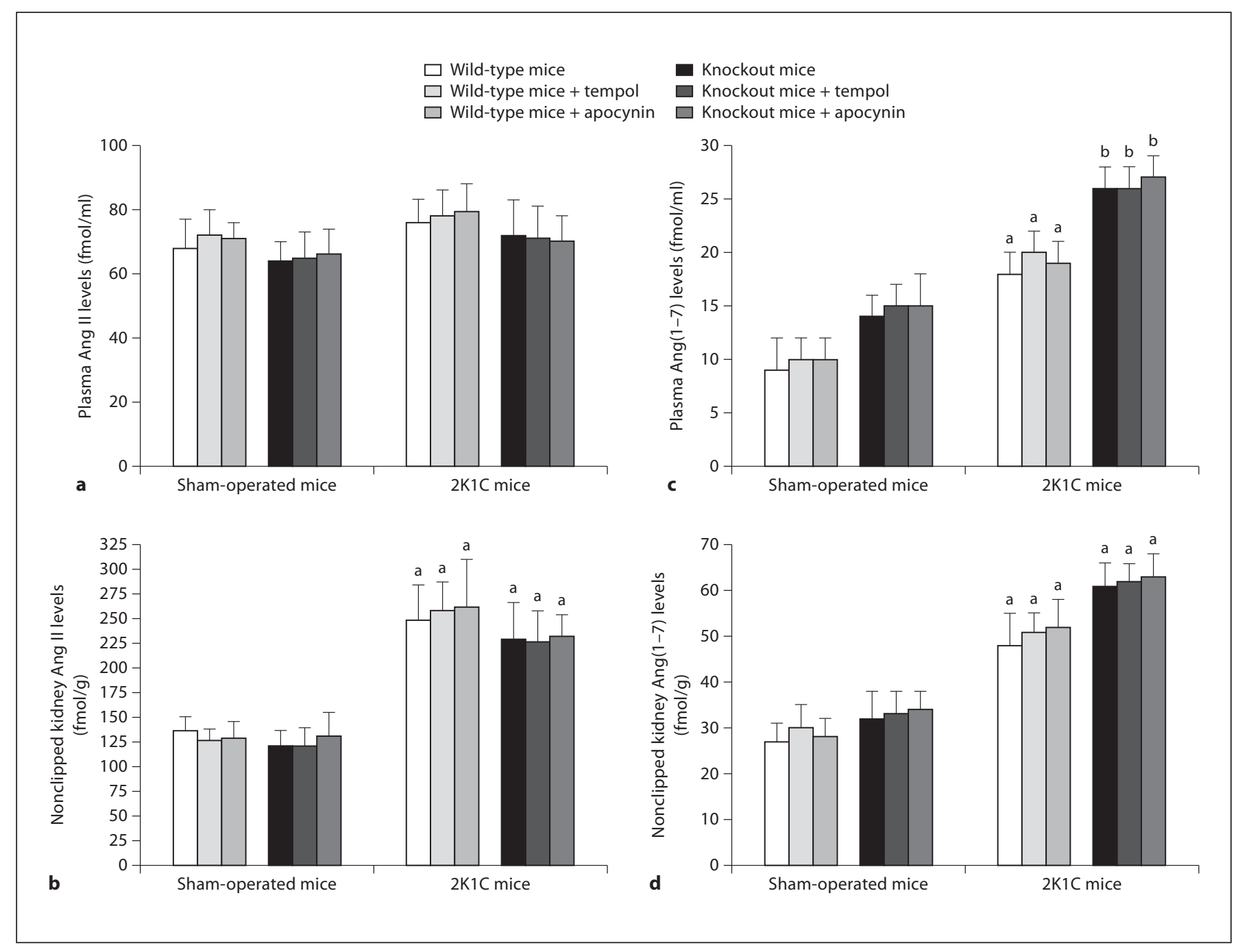

Fig. 4. Plasma (a, c) and nonclipped kidney (b, d) Ang II and Ang(1-7) levels at the end of experiments. Tempol and apocynin: chronic administration of these drugs in drinking water. ${ }^{a} \mathrm{p}<0.05$ compared with unmarked values; ${ }^{b} \mathrm{p}<0.05$ compared with all other values.

7) levels were significantly higher in $2 \mathrm{~K} 1 \mathrm{C} / \mathrm{knockout}$ mice than in $2 \mathrm{~K} 1 \mathrm{C} /$ wild-type mice $(26 \pm 2$ vs. $18 \pm$ $2 \mathrm{fmol} / \mathrm{ml}, \mathrm{p}<0.05)$. Likewise, there were no significant differences between whole kidney Ang(1-7) levels in sham-operated wild-type and knockout mice, but on day 26 after clipping whole kidney Ang(1-7) levels were significantly higher than in sham-operated wild-type and knockout mice [48 \pm 7 (wild-type) and $61 \pm 5 \mathrm{fmol} / \mathrm{g}$ (knockout) vs. $27 \pm 4$ (sham-operated wild-type) and 32 $\pm 6 \mathrm{fmol} / \mathrm{g}$ (sham-operated knockout), $\mathrm{p}<0.05$ in both cases] (fig. 4d). Chronic treatment with tempol or apocynin did not alter plasma and whole kidney Ang(1-7) levels in any of the experimental groups.

2K1C Hypertension in Mas Receptor Knockout Mice
There were no significant differences in heart Ang II and Ang(1-7) concentrations between sham-operated wild-type and knockout mice $(24 \pm 3$ vs. $21 \pm 5$ and 11 \pm 2 vs. $9 \pm 2 \mathrm{fmol} / \mathrm{g}$ ). In addition, they were not altered by either clip placement or chronic treatment with tempol or apocynin in any of the experimental groups.

\section{Series 4: Responses of MAP to Bolus Doses of Ang II} and Norepinephrine

Basal values of MAP in anesthetized sham-operated wild-type and knockout mice and in $2 \mathrm{~K} 1 \mathrm{C} /$ wild-type and $2 \mathrm{~K} 1 \mathrm{C} /$ knockout mice either untreated or tempol- or apocynin-treated were almost identical to those in series 


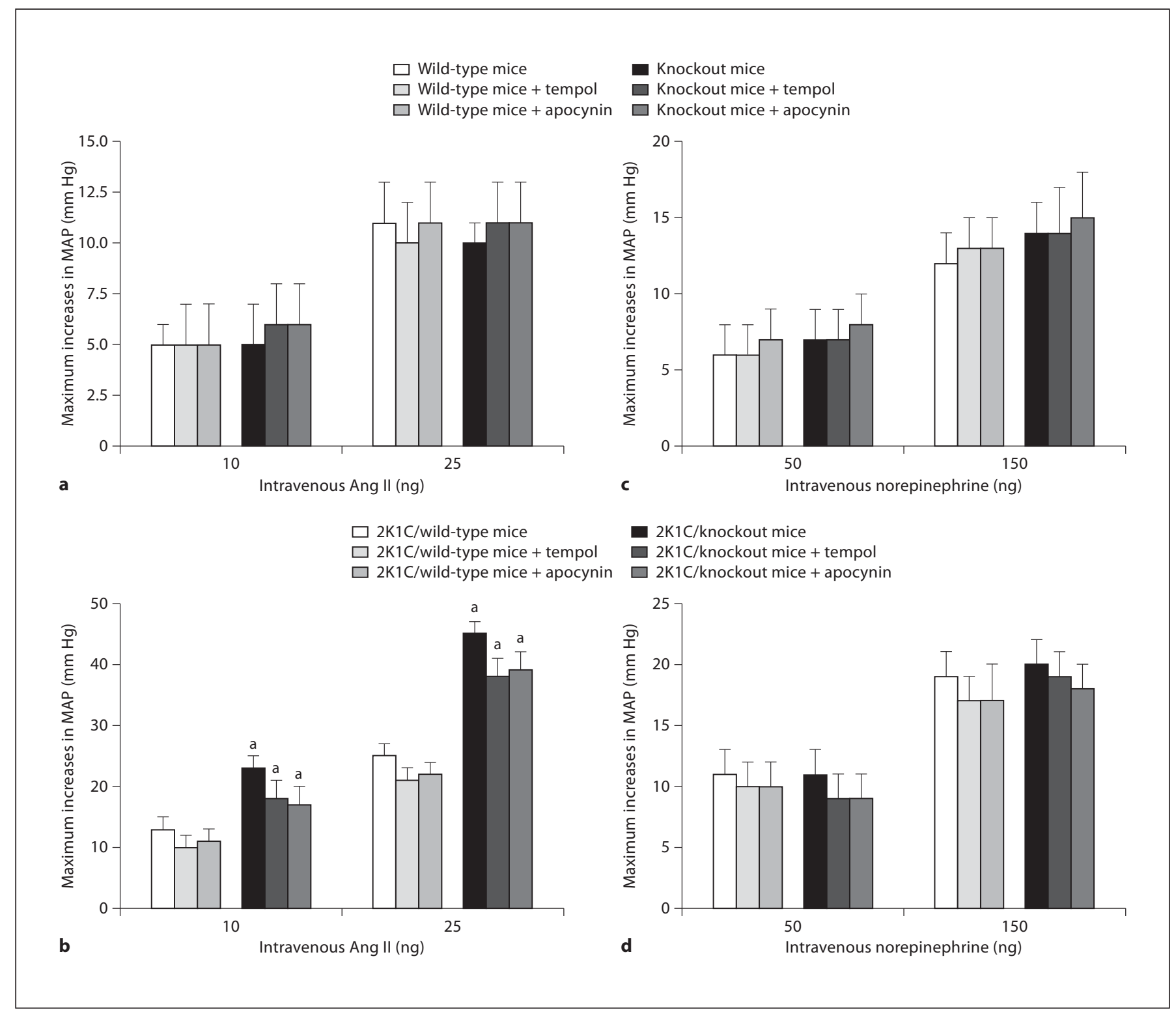

Fig. 5. Maximum increases in MAP in response to intravenous bolus administration of Ang II (a, b) and of norepinephrine (c, d) in sham-operated and 2K1C mice. Tempol and apocynin: chronic administration of these drugs in drinking water. ${ }^{a} \mathrm{p}<0.05$ compared with unmarked values in response to the same dose.

2 (confirming data obtained from conscious mice when MAP was measured by the radiotelemetric method).

As shown in figure $5 \mathrm{a}$, increases in MAP in response to intravenous bolus administration of 10 and $25 \mathrm{ng}$ of Ang II were similar in sham-operated wild-type and in knockout mice. In contrast, responses of MAP were significantly greater in $2 \mathrm{~K} 1 \mathrm{C} / \mathrm{knockout}$ mice than in $2 \mathrm{~K} 1 \mathrm{C} /$ wild-type mice ( $+23 \pm 2$ vs. $+13 \pm 2$ and $+45 \pm 2$ vs. +25 $\pm 2 \mathrm{~mm} \mathrm{Hg}$, respectively, $\mathrm{p}<0.05$ in both cases). Chron- ic treatment with tempol or apocynin did not modify MAP responses to intravenous bolus doses of Ang II in any of the experimental groups of mice (fig. 5b).

Figure $5 \mathrm{c}$ and $\mathrm{d}$ shows that the intravenous administration of 50 and $150 \mathrm{ng}$ of norepinephrine elicited similar increases in MAP in all groups of sham-operated and $2 \mathrm{~K} 1 \mathrm{C}$ wild-type as well as knockout mice. 


\section{Discussion}

A first major finding of this study is that target disruption of Mas receptor for Ang(1-7) worsened the development as well as the course of 2K1C Goldblatt hypertension. This was associated with decreased urinary nitrate/ nitrite excretion and attenuated responses of MAP to acute NOS inhibition in $2 \mathrm{~K} 1 \mathrm{C} / \mathrm{knockout}$ mice as compared with $2 \mathrm{~K} 1 \mathrm{C} /$ wild-type mice. In addition, $2 \mathrm{~K} 1 \mathrm{C} /$ knockout mice exhibited a selectively enhanced vascular responsiveness to Ang II as compared with $2 \mathrm{~K} 1 \mathrm{C} /$ wildtype mice. Altogether, these data strongly support the recently proposed concept that the ACE2-Ang(1-7)-Mas axis serves as an important endogenous vasodilatory system that partially attenuates the hypertensinogenic actions of an inappropriately activated RAS $[6-8,15,36]$. Moreover, our data - i.e. the lower urinary nitrate/nitrite excretion and the reduced response of MAP to acute NOS blockade - suggest that impaired NO release/activity as a consequence of the interruption of the ACE2-Ang(1-7)Mas axis is the underlying mechanism responsible for the worsening of the course of hypertension during the developmental as well as the maintenance phase in $2 \mathrm{~K} 1 \mathrm{C} /$ knockout mice.

In this context, it is of special interest that at the end of the experiment plasma Ang II levels in 2K1C mice were similar to those observed in sham-operated mice and that they were not altered by pharmacological treatment or by gene targeting of the Mas receptor. However, it is important to note that even normal plasma Ang II levels in 2K1C mice should be considered as inappropriately high for the level of BP and, as it has been demonstrated previously, they may contribute to some extent to the maintenance of hypertension during the sustained phase of 2K1C Goldblatt hypertension. Furthermore, intrarenal Ang II concentrations in the nonclipped kidney of $2 \mathrm{~K} 1 \mathrm{C}$ mice were markedly elevated in wild-type as well as knockout mice when compared with sham-operated mice. However, neither gene targeting itself nor pharmacological treatment with tempol or apocynin did alter kidney Ang II levels in any of the experimental groups. These data further emphasize the critical role of intrarenal Ang II content of the nonclipped kidney in the pathophysiology of 2K1C hypertension and are in accordance with results from previous studies indicating that an impaired ability to suppress intrarenal Ang II content in relation to BP elevations is the main pathophysiological mechanism responsible for the maintenance of hypertension in the $2 \mathrm{~K} 1 \mathrm{C}$ Goldblatt form of hypertension $[1-5,14]$.

2K1C Hypertension in Mas Receptor Knockout Mice
Of special interest are also our findings regarding the role of Ang(1-7), since we found that plasma and intrarenal Ang(1-7) levels after clipping were significantly increased when compared with sham-operated wild-type as well as knockout mice. Furthermore, the finding that plasma Ang(1-7) levels in $2 \mathrm{~K} 1 \mathrm{C} / \mathrm{knockout} \mathrm{mice} \mathrm{were} \mathrm{sig-}$ nificantly higher than the levels observed in $2 \mathrm{~K} 1 \mathrm{C} /$ wildtype mice suggests that Ang(1-7) exerts a negative shortloop feedback effect of Mas receptor activation on circulating Ang(1-7) levels; the elevated plasma Ang(1-7) levels in $2 \mathrm{~K} 1 \mathrm{C} / \mathrm{knockout}$ are thus the consequence of the interruption of the ACE2-Ang(1-7)-Mas axis under condition of increased RAS activity.

It is noteworthy to emphasize that we found significantly higher Ang(1-7) levels in $2 \mathrm{~K} 1 \mathrm{C} /$ knockout mice than in $2 \mathrm{~K} 1 \mathrm{C} /$ wild-type mice. In view of our current knowledge of the biochemical properties of the ACE2Ang(1-7)-Mas axis [6-8], one would expect that Ang II levels should result in significant decreases in Ang II concentrations in $2 \mathrm{~K} 1 \mathrm{C} / \mathrm{knockout}$ mice as compared with levels in $2 \mathrm{~K} 1 \mathrm{C} /$ wild-type mice. However, we did not observe such expected decreases in plasma and nonclipped kidney Ang II tissue levels in $2 \mathrm{~K} 1 \mathrm{C} / \mathrm{knockout}$ mice. We cannot offer a fully satisfactory explanation for our present findings. Further studies are required to address this issue.

Altogether, these findings further support the notion that Ang(1-7) serves as an important endogenous agent counterbalancing the hypertensinogenic actions of Ang II under conditions of increased RAS activity $[6-8,13,14$, 36].

The second new finding of our present study is that on days 21 and 25 after clipping urinary excretion rates of 8 -isoprostane, which has been repeatedly demonstrated as a reliable marker for the assessment of endogenous $\mathrm{O}_{2}^{-}$ production [25-27, 37, 38], were elevated to the same levels in untreated $2 \mathrm{~K} 1 \mathrm{C} /$ wild-type and untreated $2 \mathrm{~K} 1 \mathrm{C} /$ knockout mice. Moreover, chronic treatment with the $\mathrm{O}_{2}^{-}$ scavenger tempol or the NADPH inhibitor apocynin reduced the excretion rate of 8 -isoprostane to values observed before clipping. In addition, chronic treatment with tempol and apocynin exhibited similar BP-lowering effects in $2 \mathrm{~K} 1 \mathrm{C} /$ wild-type as in $2 \mathrm{~K} 1 \mathrm{C} / \mathrm{knockout}$ mice. These observations are in good agreement with recent findings showing that $2 \mathrm{~K} 1 \mathrm{C}$ Goldblatt hypertensive mice exhibit an impaired NOS-dependent vasodilatation during the maintenance phase of hypertension [4]. Our present data show that this is due to enhanced oxidative stress in $2 \mathrm{~K} 1 \mathrm{C}$ mice. However, our present results do not corroborate our original hypothesis that the interruption of the ACE2-Ang(1-7)-Mas axis will further increase the $\mathrm{O}_{2}^{-}$

Kidney Blood Press Res 2010;33:476-488 
formation and thereby contribute to the worsening of hypertension during the maintenance of $2 \mathrm{~K} 1 \mathrm{C}$ Goldblatt hypertension. In fact, the aforementioned data show that the level of oxidative stress is similar in $2 \mathrm{~K} 1 \mathrm{C} /$ wild-type as in $2 \mathrm{~K} 1 \mathrm{C} /$ knockout mice. However, in this context it is important to note that in our study tissue endothelial NOS expression and activity as well as tissue $\mathrm{O}_{2}^{-}$production have not been evaluated because the design of the chronic experiment with subsequent dynamic analyses does not allow tissue sampling for evaluation of the NO and $\mathrm{O}_{2}^{-}$tissue production. We are aware that this represents a limitation of the present study and future experiments are required to address this issue.

The third important finding of our study is that under control conditions knockout mice do not exhibit an impaired cardiovascular phenotype. Thus, BP is within normotensive levels, $\mathrm{NO}$ bioavailability and $\mathrm{O}_{2}^{-}$production as well as BP responses to acute NOS inhibition and peripheral and renal vascular responsiveness to vasoconstrictor agents and plasma, kidney and heart tissue concentrations of Ang II and Ang(1-7) were not significantly different from values observed in sham-operated wild-type mice. These results indicate that genetically engineered interruption of the ACE2-Ang(1-7)-Mas axis itself does not affect the cardiovascular phenotype, although we have not specifically addressed cardiac function in this study. These findings are in good agreement with our recent studies showing that pharmacologically induced interruption of the ACE2-Ang(1-7)-Mas axis under conditions of normal RAS activity does not lead to increases in BP. Only under circumstances of an activated endogenous RAS blockade of the endogenous ACE2Ang(1-7)-Mas axis does it result in further deterioration of the course of Ang II-dependent hypertension [14]. In addition, our current results are in accordance with data demonstrating that under basal conditions ACE2-deficient mice do not exhibit alterations in resting BP levels. However, they exhibit an increased sensitivity to the development of Ang II-dependent hypertension when compared with their wild-type control mice [39]. Moreover, our present findings are also in good agreement with the recent observation by Wysocki et al. [40] who showed that administration of soluble human recombinant ACE2 does not alter BP in normotensive mice but prevents the development of Ang II-dependent hypertension. Taken together, these findings further support our original hypothesis that the ACE2-Ang(1-7)-Mas axis serves as an endogenous physiological counterbalancing system that, at least partially, attenuates the hypertensinogenic actions of Ang II.
Nevertheless, it is important to note that we found under basal conditions in our knockout mice a normal cardiovascular phenotype. These findings are, on the one hand, in accordance with the results of previous studies employing Mas receptor-deficient mice $[15,41]$ but, on the other hand, they are in contrast to previously published data showing that Mas receptor-deficient mice exhibit higher basal BP than wild-type mice and this was associated with decreased $\mathrm{NO}$ formation, increased $\mathrm{O}_{2}^{-}$ production and endothelial dysfunction $[12,15]$. Since it is now well known that the genetic background is an important factor influencing cardiovascular parameters and especially basal BP levels in mice [42], it has been suggested that the different genetic background of Mas-deficient mice can be an explanation for the variability of basal cardiovascular phenotype in these mice. This notion has been further supported by findings demonstrating that the different genetic background substantially modified the cardiovascular phenotype in ACE2-deficient mice [43]. However, this explanation cannot be simply applied to our experiments because in the present study knockout mice on the FVB/N genetic background were employed, i.e. the same mouse model as was used in studies in which the impaired basal cardiovascular phenotype was observed [12]. We cannot offer a satisfactory explanation for these discrepancies. One possible explanation may be related to the slightly different methodology of direct BP measurements by the radiotelemetry system employed between our present study and studies from other laboratories. In our laboratory, we routinely use the implantation of radiotelemetric probes into the left carotid artery [4], whereas other groups who compare the cardiovascular phenotype of Mas-deficient with that of wild-type mice employed implantation into the abdominal aorta through the femoral artery [12]. Thus, it is possible that a relative temporary brain ischemia produced by our methodology could have overcome the slight difference in basal BP level which was observed between knockout and wild-type mice by other groups of investigators $[12,15]$. Therefore, in view of the aforementioned information, it is still most likely that due to the lack of cardiovascular phenotypic alteration Mas-deficient mice may be ascribed to random fixation of alleles caused by genetic drift during the inbreeding procedure.

In summary, our present results clearly show that target disruption of the Mas receptor worsens the developmental as well as the maintenance phase of hypertension in $2 \mathrm{~K} 1 \mathrm{C}$ mice. In addition, our data demonstrate that the disruption of the Mas receptor results in an impaired NO release/activity in 2K1C Goldblatt hypertensive mice. 
Moreover, these data suggest that target disruption of Mas receptor does not further increase oxidative stress during the maintenance phase of $2 \mathrm{~K} 1 \mathrm{C}$ Goldblatt hypertension. Finally, we show that target disruption of the Mas receptor specifically exaggerates the vascular responsiveness to Ang II in 2K1C Goldblatt hypertensive mice.

Collectively, based on our present results, we suggest that Ang(1-7)-induced activation of the Mas receptor serves as an important physiologic endogenous counterbalancing mechanism that partially attenuates the hypertensinogenic actions of inappropriately elevated Ang II levels in $2 \mathrm{~K} 1 \mathrm{C}$ hypertensive mice. Finally, our results indicate that an impairment of the endogenous ACE2Ang(1-7)-Mas axis contributes to the deterioration of the course of 2K1C Goldblatt hypertension.

\section{Acknowledgements}

This study was supported by grant No. IAA 511-700-701 awarded to M.B. by the Grant Agency of Academy of Science of Czech Republic (GAAV). This study was also financially supported by the EU by the Operational Program Prague - Competitiveness, project 'CEVKOON' (No. CZ.2.16/3.1.00/22126). Z.V. and I.N. are partly supported by the Center for Cardiovascular Research (1M6798582302). L.Č. receives institutional financial support from the Institute for Clinical and Experimental Medicine (MZO 00023001) and by grant No. 305/08/J006 awarded by the Czech Science Foundation (GAČR) and by grant NS/10499-3 from the Internal Grant Agency of the Ministry of Health of the Czech Republic. I.V. is supported by grants No. 305/07/0167 and No. 305/07/J004 awarded by GAČR and by grant NS/9703-4 awarded by the Internal Grant Agency of the Ministry of Health of the Czech Republic. Z.H. is supported by grant No. 305/08/ P053 awarded by GAČR. H.J. Kramer is supported by grants from the German Research Foundation (Deutsche Forschungsgemeinschaft), Bonn (Kra 436/14-2 and 436 TSE 113/57/0-1).

\section{References}

-1 Navar LG, Zou L, Von Thun A, Wang CT, Imig JD, Mitchell KD: Unraveling the mystery of Goldblatt hypertension. News Physiol Sci 1998;13:170-176.

-2 Kobori H, Nangaku M, Navar LG, Nishiyama A: The intrarenal renin-angiotensin system: from physiology to the pathobiology of hypertension and kidney disease. Pharmacol Rev 2007;59:251-287.

-3 Cervenka L, Wang CT, Mitchell KD, Navar LG: Proximal tubular angiotensin II levels and renal functional responses to $\mathrm{AT}_{1}$ receptor blockade in nonclipped kidneys of Goldblatt hypertensive rats. Hypertension 1999; 33:102-107.

-4 Červenka L, Vaněčková I, Husková Z, Vaňourková Z, Erbanová M, Thumová M, Škaroupková P, Opočenský M, Malý J, Čertíková Chábová V, Tesař V, Bürgelová $\mathrm{M}$, Viklický O, Teplan V, Želízko M, Kramer HJ, Navar LG: Pivotal role of $\mathrm{AT}_{1 \mathrm{~A}}$ receptors in the development of two-kidney, one-clip hypertension: study in $\mathrm{AT}_{1 \mathrm{~A}}$ receptor knockout mice. J Hypertens 2008;26:1379-1389.

-5 Walkowska A, Škaroupková P, Husková Z, Vaňourková Z, Čertíková Chábová V, Tesař V, Kramer HJ, Falck JR, Imig JD, Kompanovska-Jezierska E, Sadowski J, Červenka L: Intrarenal cytochrome P-450 metabolites of arachidonic acid in the regulation of the nonclipped kidney function in two-kidney, one-clip Goldblatt hypertensive rats. J Hypertens 2010;28:582-593.

-6 Iusuf D, Henning RH, van Gilst WH, Roks AJ: Angiotensin-(1-7): pharmacological properties and pharmacotherapeutic perspectives. Eur J Pharmacol 2008;585:303312 .
7 Santos RAS, Ferrerira AJ, Simoes e Silva AC: Recent advances in the angiotensin-converting enzyme2-angiotensin(1-7)-Mas axis. Exp Physiol 2008;93:519-527.

8 Ingelfinger JR: Angiotensin-converting enzyme 2: implications for blood pressure and kidney disease. Curr Opin Nephrol Hypertens 2009;18:79-84.

-9 Santos RAS, Simoes e Silva AC, Maric C, Silva DM, Machado RP, de Buhr I, HeringerWalter S, Pinheiro SV, Lopes MT, Bader M, Mendes EP, Lemons VS, Campagnole-Santos MJ, Schultheiss HP, Speth R, Walther T: Angiotensin-(1-7) is an endogenous ligand for the $G$ protein-coupled receptor Mas. Proc Natl Acad Sci USA 2003;100:8258-8263.

10 Kostenis E, Milligan G, Christopoulos A, Sanchez-Ferrer CF, Heringer-Walter S, Sexton PM, Gembardt F, Kellet E, Martini L, Vanderheyden P, Walther T: G-protein-coupled receptor Mas is a physiological antagonist of the angiotensin II type 1 receptor. Circulation 2005; 111:1806-1813.

-11 Carvalho MBL, Duarte FV, Faria-Silva R, Fauler B, da Mata Machado LT, de Paula RD, Campagnole-Santos MJ, Santos RA: Evidence for Mas-mediated bradykinin potentiation by the angiotensin-(1-7) nonpeptide mimic AVE 0991 in normotensive rats. Hypertension 2007;50:762-767.

12 Xu P, Costa-Gocalves A, Todiras M, Rabelo LA, Sampaio WO, Moura MM, Santos SS Luft FC, Bader M, Gross V, Alenina N, Santos RA: Endothelial dysfunction and elevated blood pressure in Mas gene-deleted mice. Hypertension 2008;51:574-580.
13 Bürgelová M, Kramer HJ, Teplan V, Thumová M, Cervenka L: Effects of angiotensin-(1-7) blockade on renal function in rats with enhanced intrarenal ANG II activity. Kidney Int 2005;67:1453-1461.

14 Bürgelová M, Vaňourková Z, Thumová M, Dvořák $\mathrm{P}$, Opočenský $\mathrm{M}$, Kramer HJ, Dvořák P, Červenka L: Impairment of the angiotensin-convertin enzyme 2-angiotensin-(1-7)Mas axis contributes to the acceleration of two-kidney, one-clip Goldblatt hypertension. J Hypertens 2009;27:1988-2000.

15 Alenina N, Xu P, Rentzsch B, Patkin EL, Bader M: Genetically altered animal models for Mas and angiotensin-(1-7). Exp Physiol 2008;93:528-537.

16 Bürgelová M, KramerHJ, Teplan V, Veličková G, Vítko S, Heller J, Malý J, Červenka L: Intrarenal infusion of angiotensin-(1-7) modulates renal functional responses to exogenous angiotensin II in the rat. Kidney Blood Press Res 2002;25:202-210.

17 Heller J, Kramer HJ, Malý J, Červenka L, Horáček V: Effect of intrarenal infusion of angiotensin-(1-7) in the dog. Kidney Blood Press Res 2000;23:89-94

18 Navar LG, Ichihara A, Chin SY, Imig JD: Nitric oxide-angiotensin II interactions in angiotensin II-dependent hypertension. Acta Physiol Scand 2000;168:139-147.

19 Mitchell KD, Botros FT, Navar LG: Intrarenal renin-angiotensin system and counteracting protective mechanisms in angiotensin II-dependent hypertension. Acta Physiol Hung 2007;94:31-48.

20 Faria-Silva R, Duarte FV, Santos RAS: Shortterm angiotensin-(1-7) receptor Mas stimulation improves endothelial function in normotensive rats. Hypertension 2005;46: 948-952. 
-21 Sampai WO, Santos RAS, Faria-Silva R, da Mata Machado LT, Schiffrin EL, Touyz RM: Angiotensin-(1-7) through receptor Mas mediates endothelial nitric oxide synthase activation via Akt-dependent pathways. Hypertension 2007;49:185-192.

22 Červenka L, Horáček V, Vaněčková I, Hubáček JA, Oliverio MI, Coffman TM, Navar LG: Essential role of $\mathrm{AT}_{1 \mathrm{~A}}$ receptor in the development of $2 \mathrm{~K} 1 \mathrm{C}$ hypertension. Hypertension 2002;40:735-741.

23 Sampaio WO, Castro CH, Santos RAS, Schiffrin EL, Touyz RM: Angiotensin-(1-7) counterregulates angiotensin II signaling in human endothelial cells. Hypertension 2007; 50:1093-1098.

24 Ortiz PA, Garvin JL: Superoxide stimulates $\mathrm{NaCl}$ absorption by the thick ascending limb. Am J Physiol 2002;283:F957-F962.

-25 Kopkan L, Husková Z, Vanourková Z, Thumová M, Skaroupková P, Cervenka L, Majid DS: Superoxide and its interaction with nitric oxide modulates renal function in prehypertensive Ren-2 transgenic rats. J Hypertens 2007;25:2257-2265.

26 Elmarakby AA, Williams JM, Imig JD, Pollock JS, Pollock DM: Synergistic actions of enalapril and tempol during chronic angiotensin II-induced hypertension. Vascul Pharmacol 2007;46:144-151.

-27 Kopkan L, Husková Z, Vaňourková Z, Thumová M, Šakroupková P, Malý J, Kramer HJ, Dvořák P, Červenka L: Reduction of oxidative stress does not attenuate the development of angiotensin II-dependent hypertension in Ren-2 transgenic rats. Vascul Pharmacol 2009;51:175-181.

28 Virdis A, Neves MF, Amiri F, Touyz RM, Schiffrin EL: Role of NAD(P)H oxidase on vascular alterations in angiotensin II-infused mice. J Hypertens 2004;22:535-542.
29 Husková Z, Kramer HJ, Thumová M, Vaňourková Z, Bürgelová M, Teplan V, Červenka L: Effects of anaesthesia on plasma and kidney ANG II levels in normotensive and ANG II-dependent hypertensive rats. Kidney Blood Press Res 2006;29:74-83.

30 Fox J, Guan S, Hymel AA, Navar LG: Dietary $\mathrm{Na}$ and ACE inhibition effects on renal tissue angiotensin I and II and ACE activity in rats. Am J Physiol 1992;262:F902-F909.

-31 Kopkan L, Kramer HJ, Huskova Z, Vaňourková Z, Škaroupková $P$, Thumová $M$, Červenka L: The role of intrarenal angiotensin II in the development of hypertension in Ren-2 transgenic rats. J Hypertens 2005;23: 1531-1539.

\$2 Vaňourková Z, Kramer HJ, Husková Z, Vaněčková I, Opočenský O, Čertíková Chábová $\mathrm{V}$, Tesař $\mathrm{V}$, Thumová $\mathrm{M}$, Dohnalová $\mathrm{M}$, Mullins JJ, Červenka L: $\mathrm{AT}_{1}$ receptor blockade is superior to conventional triple therapy in protecting against end-organ damage in Cypla1-Ren-2 transgenic rats with inducible hypertension. J Hypertens 2006;24:24652472.

33 Erbanová M, Thumová M, Husková Z, Vaněčková I, Vaňourková Z, Mullins JJ, Kramer HJ, Bürgelová $M$, Rakušan $D$, Červenka L: Impairment of the autoregulation of renal hemodynamics and the pressure-natriuresis relationship precedes the development of hypertension in Cypla1Ren-2 transgenic rats. J Hypertens 2009;27: 575-586.

34 Čertíková Chábová V, Kramer HJ, Vaněčková I, Vernerová Z, Eis V, Tesař V, Škaroupková P, Thumová M, Schejbalová S, Husková Z, Vaňourková Z, Kolský A, Imig J, Červenka L: Effects of chronic cytochrome P-450 inhibition on the course of hypertension and endorgan damage in Ren-2 transgenic rats. Vascul Pharmacol 2007;47:145-159.
35 Jacinto SM, Mullins JJ, Mitchell KD: Enhanced renal vascular responsiveness to angiotensin II in hypertensive ren-2 transgenic rats. Am J Physiol 1999;276:F315-F322.

- 36 Dilauro M, Burns KD: Angiotensin-(1-7) and its effects in the kidney. ScientificWorldJournal 2009;9:522-535.

37 Reckelhoff JF, Romero JC: Role of oxidative stress in angiotensin-induced hypertension. Am J Physiol 2003;284:R893-R912.

38 Wilcox CS: Oxidative stress and nitric oxide deficiency in the kidney: a critical link to hypertension? Am J Physiol 2005;289:R913R935.

- 39 Gurley SB, Allred A, Le TH, Griffiths R, Mao L, Philip N, Haystead TA, Donoghue M, Breitbart RE, Acton SL, Rockman HA, Coffman TM: Altered blood pressure responses and cardiac phenotype in ACE2-null mice. J Clin Invest 2006;116:2218-2225.

-40 Wysocki J, Ye M, Rodriguez E, González-Pacheco FR, Barrios C, Evora K, Schuster M, Loibner $\mathrm{H}$, Brosnihan KB, Ferrario CM, Penninger JM, Battle D: Targeting the degradation of angiotensin II with recombinant angiotensin-converting enzyme 2. Prevention of angiotensin II-dependent hypertension. Hypertension 2010;55:90-98.

41 Walther T, Wessel N, Kang N, Sander A, Tschope C, Malberg H, Bader M, Voss A: Altered heart rate and blood pressure variability in mice lacking the Mas protooncogene. Braz J Med Biol Res 2000;33:1-9.

-42 Deschepper CF, Olson JL, Otis M, GalloPayet N: Characterization of blood pressure and morphological traits in cardiovascularrelated organs in 13 different inbred mouse strains. J Appl Physiol 2004;97:369-376.

43 Gurley SB, Coffman TM: Angiotensin-converting enzyme 2 gene targeting studies in mice: mixed messages. Exp Physiol 2008;93: 538-542. 